Available online at: https://journals.researchsynergypress.com/index.php/ijmesh

International Journal of Management, Entrepreneurship, Social Science and Humanities

(IJMESH)

ISSN 2580-0981 (online)

Volume 4 Issue 1 (2021): 32-40

\title{
Impact of Work-From-Home Policy on Behavior and Productivity of Lecturers and Education Staff
}

\author{
Afni Sirait ${ }^{1}$, Sri Luna Murdianingrum ${ }^{2}$ \\ 1,2 Faculty of Economy and Business, Universitas Pembangunan Nasional "Veteran" Yogyakarta
}

\begin{abstract}
To break the chain of COVI-19 virus, Work-From-Home (WFH) policy is enforce to the university in Indonesia and among place is the Faculty Economy and Business (FEB) Universitas Pembangunan Nasional "Veteran" at Yogyakarta. This research purpose is to identify the influence of WFH on productivity of lecturers and education staff with technology as its intermediate variable, during this COVID-19 policy. This study uses quantitative methods with 96 (80\%) from 120 respondents. The data was collected using a questionnaire, then tested the validity, reliability, and evaluation of the model structure using data analysis tools SmartPLS 3.0.0. The results of data processing explained that there was no relationship between WFH and technology-mediated behaviour (P-Value = 0.297; T-Statistic $=1.043$ ). A different yield of WFH data processing with productivity. It was found positive and significant influence but mediated partially competitive by technology. The path coefficient value of the direct relationship between WFH and productivity is 0.206 (P-Value 0.034; T-Statistic $=2.132$ ) that the indirect relationship between WFH and productivity is mediating by the technology of 0.353 . The limitation of this research is that it is only carried out in, our sample, not yet in a comprehensive manner at the University level, yet as we leave as a part of our future research direction.
\end{abstract}

Keywords: Productivity, Behavior, Work-From-Home

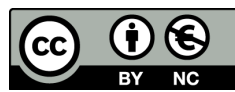

This is an open access article under the CC-BY-NC license

\section{INTRODUCTION}

Work-From-Home (WFH) policy is new method of work in Indonesia. This implementation of this policy during pandemic COVID-19 in Indonesia. WFH give many impacts for worker such as work without boundary, flexibility time, and unlimited time for working. Working with WFH method will be successful if every-body in this network working with good technology. This method working organized, controlling, and managing working with technology that is internet. Flexibility time and working without strict rules decline stress level for worker. This situation increase productivity and building a new behaviour for working.

The results of research conducted by Frey et al (2020) stated that during the COVID-19 pandemic the use of technology in the education industry increased by around $12.5 \%$ and will continue to rise. Rapp, Tirassa, \& Tirabeni (2019) in their research explain that human and computer interactions design a lot of technology used to support changes in human behaviour. Technology makes it easier for humans to move and fulfil their needs.

Erickson, Moulton, \& Cleary (2018) issued a review stating that the use of technology at work hurts employees. The use of technology that can be used anywhere and anytime increases employee working hours more than it should. Even workplace conditions that are too dependent on technology have caused some employees to become Research methods should make readers be able to reproduce the analysis. Provide sufficient detail to allow the work to be reproduced. 
International Journal of Management, Entrepreneurship, Social Science and Humanities (IJMESH), Vol. 4 (1), 32-40

Impact of Work-From-Home Policy on Behavior and Productivity of Lecturers and Education Staff

Afni Sirait; Sri Luna Murdianingrum

Methods already published should be indicated by a reference: only relevant modifications should be described. Figures are sequentially numbered commencing at 1 with the figure title and number below the figure as shown in Figure 1.

Addicted and unable to escape from it. Rupietta \& Beckmann (2018) stated that employees who work from home have the freedom to independently schedule their work and have high motivation from within. Companies like Google and several other companies use the WFH method to increase the creativity, innovation and performance of their employees.

The Indonesian government is doing almost the same thing as the Chinese government to tackle the spread of this virus by issuing Presidential Decree No. 7 of 2020 concerning the Task Force for the Acceleration of Handling Coronavirus Disease 2019. This regulation and Task Force State that learn from home, works from home by creating on-line interactions, delaying activities that involve many people, and improving services in the health sector for testing and healing Covid19 patients.

Educational institutions as one of the public services are expected by the government to be able to use technology platforms to carry out learning and work from home. Figure 1 presents that the education industry is one of the industries that is affected and has the potential for failure. The Faculty of Economics and Business, UPN "Veteran" Yogyakarta as a government agency faces challenges in carrying out its duties and functions. This challenge is not only from the government but also to the community as stakeholders.

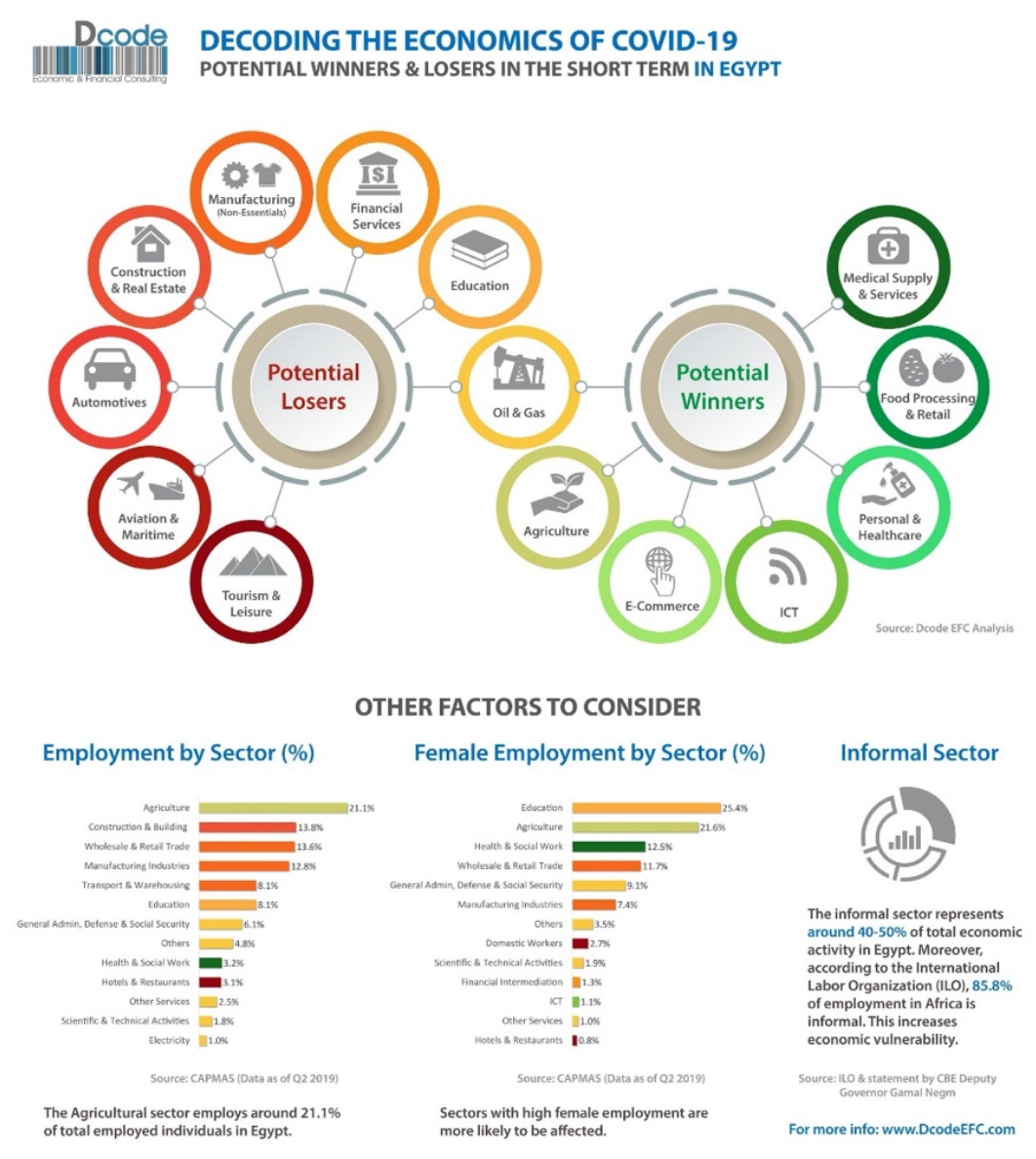

Figure 1. Decoding The Economics of COVID-19

The Faculty of Economics and Business as one of the faculties at UPN "Veteran" Yogyakarta carries out its duties and functions by using technology or based on online.

(C) 2021 International Journal of Management, Entrepreneurship, Social Science and Humanities (IJMESH)

ISSN 2580-0981 (online) 
This starts with conducting the Mid-Semester Examination on March 17, 2020 online until lectures after Mid-Semester. Thesis consultation or guidance also uses the same thing between lecturers and students. The appeal to work from home or Work From-Home (WFH) is applied obediently by the academic community in the FEB UPN "Veteran" Yogyakarta.

The background described above underlies researchers to research the impact of policies implemented on academic behavior and performance as an impact of policy implementation by agencies. Behavior and performance are important concerns considering the duties and responsibilities of lecturers and educators of FEB UPN "Veteran" Yogyakarta as public servants.

\section{Research Contribution}

This research makes a positive contribution to the institution as an additional consideration for stakeholders for planning preventive actions in facing uncertain conditions in the future, especially with academic services. Contribute to science and the world of education in measuring the productivity of lecturers and education personnel so that they have clear basics and standards, especially in the current conditions of learning and working from home.

\section{LITERATURE REVIEW}

\section{Work From-Home (WFH)}

Mungkasa (2020) explained that working from home or work from home is the responsibility of work performed by an employee for a certain period outside the office with the help of technology. The remote working categorization is divided into 3 categories. First, workers who work telecommuting. Second, the work is carried out in the satellite office and third, in mobile work.

MacRae \& Sawatzky (2020) explain that remote work is a new working method that is currently being developed. The development of this work method is due to the use of technology, not knowing demographics, the flexibility of employees related to improved productivity, job satisfaction, and agreed work contracts.

\section{Behavior}

Longino \& Longino (2015) define behavior as something or someone's actions that can be observed, measured, and repeated. This behavior can be measured using the target behavior that can be set for the assessment.

Navrátil, Hladká, David, \& Duspivová (2017) explain that Work From-Home has criteria in its implementation. WFH is a working trend that is flexible by working hours determined by the organization. Apart from being flexible, WFH also provides freedom in working hours and work processes that use technology. Terms that are often referred to in addition to WFH, such as remote work, homeworking / home office, home-based work, teleworking and others.

Nordin, Mohd Baidzowi, \& Razak (2016) states that working at home helps employees lead a balanced life without being constrained by office hours and free scheduling. Life balance is obtained from reduced stress loads, reduced transportation costs, and no reduced responsibility to the family. The use of technology helps employees in Malaysia to work from anywhere.

The results of research by Saludin, Karia, \& Hassan (2020) conducted the same study in Malaysia. The study concluded that WFH is a solution to having a balanced life and recognition. The results of this study also provide a framework that explains the factors that trigger the realization of WFH and the basic requirements that organizations must have in their implementation. The triggering factors are management, competition, nature of work, attitudes, Internet Communication Technology (ICT), knowledge, employee desires, and costs. Requirements that must be met by organizations such as space, employee status, nature of work, working hours, communication/ ICT, reward systems, employee home-work, cost savings, and legal issues. 


\section{Productivity}

Yilma Goshu, Kitaw, \& Matebu (2017) explain that productivity is the concept of using existing resources within the company by considering the effectiveness in their allocation. Gordon \& Gretton (2015)explain that good productivity growth comes from hard work and long working hours. Productivity is generated from workers or employees who work "smart". Productivity does not indicate how much the amount of output is produced but how resources are processed effectively used to produce output.

Mautz (2018) states that the extraordinary productivity of telecommunicators who work at home all day long. Employees who work at home are much more productive than employees who have to go to the office, arrive late or arrive early, which turns out to be distracting employees. The study, which was carried out for nearly 2 years, also explains that fewer employees take time off, reducing carbon emissions from motorized vehicles, saving companies about $\$ 2,000$ per employee by reducing the number of office space to rent.

The same research was conducted by Dr. Revenio C. Jalagat \& Jalagat (2019) who explain that trends and methods of working from home are currently developing. This trend is developing because of several benefits such as increased productivity, flexibility, internet access, cost savings, a better environment, and a good impact on the environment. The survey conducted by TOPCONTENT (2019) found 13 developed countries that have successfully implemented the working from home method.

A survey conducted by the Global Research Study (2020) shows that more than $72 \%$ of employees have experienced a change in work location due to the COVID-19 pandemic. The results of this survey concluded 4 important things that are happening at this time. First, workers feel that productivity is increasing compared to usual. Second, workers use technology as assistants who help work. Third, there are additional personal costs while running WFH. Fourth, the comfort of working at home raises the desire for WFH to be enforced forever.

\section{Work-From Home (WFH), Behavior, and Productivity}

Doing work from home improves one's self-welfare even though you will do homework simultaneously (Song \& Gao, 2018). A survey conducted by an economic platform explained that employees who work at home spend just 22 minutes a day off. They also work 14 - 16.8 more days a month compared to employees who work in offices. Employees who work at home only spend 27 minutes a day on unproductive activities (Beauregard, Basile, \& Canonico, 2013).

Timsal \& Awais (2016) explained that WFH has a positive impact on the company. The impact for employees is that those who usually leave for the office earlier to avoid congestion no longer need to worry about it, their stress levels are reduced due to the office environment and their increased creativity. The impact obtained by the organization is that the recruitment of reliable top management positions is no longer limited by geography and even the possibility of recruiting employees from competitors in similar industries, saves operational costs, and most importantly helps create a balance of life and work for employees.

In general, Timsal \& Awais (2016)stated that the benefits of WFH are:

1. Feeling a more flexible environment because you can set your hours;

2. Apart from stress disorders for example professional conflicts that occur in the office;

3. No distance to home and family

4. Have better health and a more balanced work life

5. The long term provides increased productivity and creativity. 
International Journal of Management, Entrepreneurship, Social Science and Humanities (IJMESH), Vol. 4 (1), 32-40

Impact of Work-From-Home Policy on Behavior and Productivity of Lecturers and Education Staff

Afni Sirait; Sri Luna Murdianingrum

Based on the existing review literature, the proposed hypothesis is presented as follows.

H1: Work From-Home (WFH) has positive impact on the behavior of faculty and academic staff with technology as intermediated variable.

$\mathrm{H}_{2}$ : Work From-Home (WFH) has a positive impact on the productivity of lecturers and educational staff mediated by technology.

\section{METHODOLOGY}

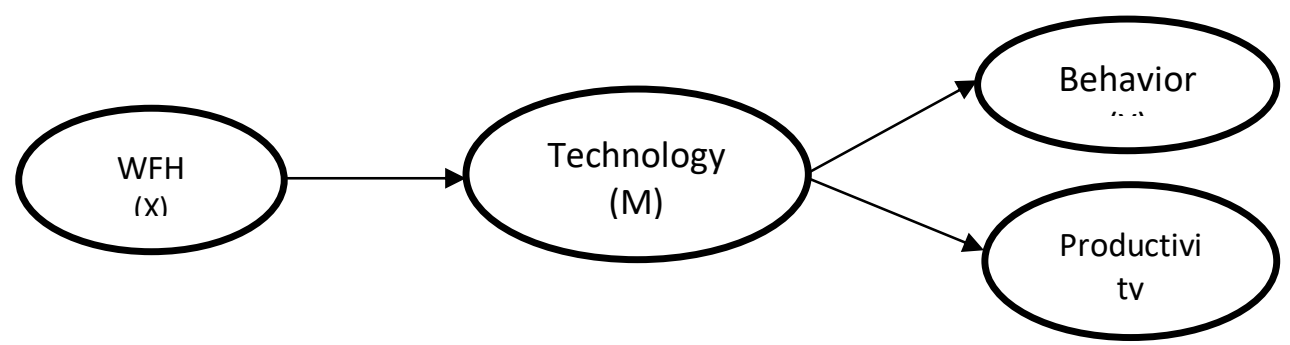

Figure 2. Hypothesis Schema

Apuke (2017) explains that research with quantitative methods is carried out to test hypotheses and test the significance and insignificance of the variables used. The design of this study used exploratory techniques using data analysis tools SmartPLS 3.0.0. The purpose of using this analysis tool is because it is exploratory or extends to existing theories. The variables used in this study consisted of 2 endogenous variables (behavior and productivity), 1 exogenous variable (WFH), and 1 mediating variable (technology). Data testing is done by testing the validity (test loading factor, AVE value, discriminant validity, and cross loading) and reliability (calculating composite reliability and Cronbach's alph). Furthermore, the model structure test is carried out using analysis R-Square, Path Coefficients, T-statistic, Predicted Relevance and Model Fit.

The population and sample of this study were 120 lecturers and educators at the Faculty of Economics and Business UPN "Veteran" Yogyakarta with a total of 96 questionnaires returned. The assessment indicators in the questionnaire use a Likert scale of 1-7 for the Behavior assessment variables. Assessment indicators for WHF, technology, and productivity variables use a Likert scale of $1-5$.

\section{RESULT AND DISCUSSION RESULTS}

The questionnaire used refers to the questionnaire prepared by the Global Workplace Analysis which is then replicated and adjusted to the conditions in the study sample. The questionnaire was distributed to 120 respondents and the questionnaire was returned with a total of 96 questionnaires. The meta data of the 96 questionnaires consisted of 48 women and 48 men. The results of the survey data from the distributed questionnaires are presented as follows. Testing the validity and reliability of data for the variables defined in this study. The validity test was done by testing the loading factor, AVE value, discriminant validity, and cross loading. Test the validity of the endogenous variable productivity using the loading factor shows that there are 5 indicators (P6, P8, P13, P14, and P15). The validity test on the behavioral endogenous variables obtained 3 indicators (Per1, Per2, and Per3). Testing the composite reliability coefficient value must be greater than 0.70 and the Average Variance Extracted (AVE) value must be greater than 0.50. The test results of the composite reliability coefficient are presented as follows. 
International Journal of Management, Entrepreneurship, Social Science and Humanities (IJMESH), Vol. 4 (1), 32-40 Impact of Work-From-Home Policy on Behavior and Productivity of Lecturers and Education Staff Afni Sirait; Sri Luna Murdianingrum

Table 1. Composite Reliability Coefficient, Cronbach's Alpha, and AVE Value

\begin{tabular}{|l|c|c|c|}
\hline & $\begin{array}{c}\text { Cronbach's } \\
\text { Alpha }\end{array}$ & $\begin{array}{c}\text { Composite } \\
\text { Reliability }\end{array}$ & $\begin{array}{c}\text { Average Variance } \\
\text { Extracted (AVE) }\end{array}$ \\
\hline Behavior (Y) & 0.869 & 0.880 & 0.717 \\
\hline Productivity (Y) & 0.943 & 0.946 & 0.661 \\
\hline Technology (M) & 0.918 & 0.922 & 0.710 \\
\hline WFH (X) & 0.967 & 0.871 & 0.794 \\
\hline
\end{tabular}

Source: Processed Data

Testing Discriminant validity is done to test the validity of the variables used in value must be greater than 0.70 ). The results of testing are discriminant validity presented in the following table.

Table 2. Discriminant Validity

\begin{tabular}{|l|l|l|l|l|}
\hline & Behavior (Y) & Productivity (Y) & Technology (M) & WFH (X) \\
\hline Behavior (Y) & $\mathbf{0 . 8 4 7}$ & 0.000 & 0.000 & 0.000 \\
\hline Productivity (Y) & 0.555 & $\mathbf{0 . 8 1 3}$ & 0.000 & 0.000 \\
\hline Technology (M) & 0.472 & 0.779 & $\mathbf{0 . 8 4 3}$ & 0.000 \\
\hline WFH (X) & 0.347 & 0.559 & 0.527 & $\mathbf{0 . 8 9 1}$ \\
\hline
\end{tabular}

Source: Processed Data

The model test value is 0.726 or $72.6 \%$ which is obtained from the NFI value. The R-Square value for the endogenous variable behavior was 0.236 , the endogenous variable productivity was 0.637 , and the mediating variable was 0.277 . The $\mathrm{P}$ value for $\mathrm{H} 1$ is 0.297 and $\mathrm{H} 2$ is 0.034 . The $\mathrm{T}$ Statistic $\mathrm{H} 1$ is 1.043 and $\mathrm{H} 2$ is 2.132 . The results of processing the model structure are presented in the following figure. The path coefficient values for each hypothesis are 0.136 and 0.206 . The value of indirect effects for $\mathrm{H} 1=0.211$ and $\mathrm{H} 2=0.353$. 


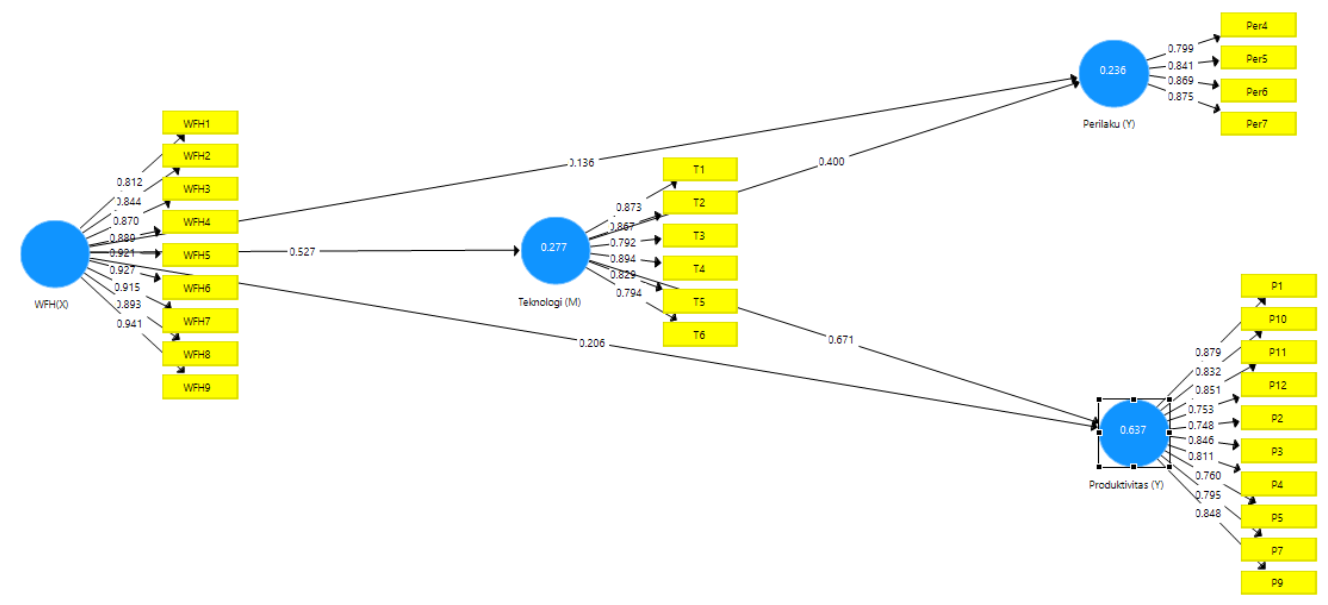

Figure 3. Structure Model Testing

\section{DISCUSSION}

The results of data processing in the analysis section above serve as material for discussion in this section. This discussion will begin with a summary of the hypothesis results that are presenting in the following table.

Table 3. Summary of Hypothesis Results

\begin{tabular}{|c|c|c|c|c|c|c|c|}
\hline $\begin{array}{c}\text { Hypothesi } \\
\mathbf{S}\end{array}$ & $\begin{array}{c}\text { Predictio } \\
\mathbf{n}\end{array}$ & $\begin{array}{c}\text { Variabl } \\
\mathbf{e}\end{array}$ & $\begin{array}{c}\text { Path } \\
\text { Coefficien } \\
\mathbf{t}\end{array}$ & $\begin{array}{c}\mathbf{P}- \\
\text { Valu } \\
\mathbf{e}\end{array}$ & $\begin{array}{c}\mathbf{T}- \\
\text { Statisti } \\
\mathbf{c}\end{array}$ & $\begin{array}{c}\text { Significan } \\
\mathbf{t}\end{array}$ & Result \\
\hline $\mathrm{H}_{1}$ & + & $\mathrm{XMY}$ & 0.136 & $\begin{array}{c}\mathrm{P}= \\
0.297\end{array}$ & $\mathrm{~T}<1.96$ & $\begin{array}{c}\text { Not } \\
\text { Significant }\end{array}$ & $\begin{array}{c}\text { Not } \\
\text { Supporte } \\
\mathrm{d}\end{array}$ \\
\hline $\mathrm{H}_{2}$ & + & $\mathrm{XMY}$ & 0.206 & $\begin{array}{c}\mathrm{P}= \\
0.034\end{array}$ & $\mathrm{~T}>1.96$ & Significant & $\begin{array}{c}\text { Supporte } \\
\mathrm{d}\end{array}$ \\
\hline
\end{tabular}

Source: Processed Data

The first hypothesis is building from literature formulated in the sentence Work From Home (WFH) has a positive effect on the behavior of lecturers and education staff mediated by technology is not accepted / not supported. Based on the results of tests carried out, the Tstatistic value is less than 1.96, which means there is no significant influence between the variables.

The seconded hypothesis is formulating in the sentence Work From Home (WFH) has a positive effect on the productivity of lecturers and education staff mediated by technology accepted/supported. Based on the results of tests carried out, the T-statistic value is more than 1.96, which means positive influence. P-value is less than 0.1 , which means a positive impact. 
International Journal of Management, Entrepreneurship, Social Science and Humanities (IJMESH), Vol. 4 (1), 32-40 Impact of Work-From-Home Policy on Behavior and Productivity of Lecturers and Education Staff Afni Sirait; Sri Luna Murdianingrum

Table 4. Direct and Indirect Effect Test Results $\mathrm{H}_{2}$

\begin{tabular}{|c|c|c|l|l|}
\hline & \multicolumn{2}{|l|}{ Direct Effect } & \multicolumn{2}{l|}{ Indirect Effect } \\
\cline { 2 - 5 } & Path coefficient & T-statistic & Path Coefficient & T-Statistic \\
\hline $\mathrm{X}-\mathrm{Y}$ & 0.206 & $\mathrm{~T}>1.96$ & & \\
\hline $\mathrm{X}-\mathrm{M}-\mathrm{Y}$ & & & 0.353 & $\mathrm{~T}>1.96$ \\
\hline
\end{tabular}

Source: Processed Data

Direct and indirect testing only carried out for $\mathrm{H} 2$ because $\mathrm{H} 1$ did not support or unaccepted from the test results. The directing test of the path coefficient test results for exogenous variables to endogenous variables is smaller than the indirect test. Wong \& Kwong-Kay (2016) explain that mediating variables used to see the direct and indirect effects of endogenous and exogenous variables in data processing using PLS.

Based on the results of hypothesis testing and the explanation above, the mediating variable in the second hypothesis only mediates partially competitively. This condition explains that there may be other factors that support the productivity of lecturers and education staff besides technology. The results of this test supported the initial aim of the researchers to determine the impact of WFH policies on changes in behavior and productivity for lecturers and education staff in the FEB UPN "Veteran" Yogyakarta. Find that the technology used during WFH did not affect behavior change. Technology has a partial effect on increasing the productivity of the implementation of duties and responsibilities for public services.

\section{CONCLUSIONS AND FURTHER RESEARCH}

The result of the processing and analysis of the research findings is the first impact of WFH as policy implementation doesn't change the behavior of lecturers and education staff mediated by technology. Second, WFH has a partial or partial competitive effect on productivity because of the mediating variable (technology).

This partially competitive effect of technology can be used as a basis for management to replace other factors that will fully support increased productivity. This productivity becomes necessary if the online study policy implementation in the 2020/2021 Academic Year. Lectures and online services are needed to maintain their quality optimally because of the duties and responsibilities of institutions as public servants in the field of educational services.

Further research should be using qualitative methods with the type of case study. The findings from this research are using as a reference for obtaining depth of research results. This method can dig deeper into other important factors that will help increase the productivity of lecturers and education staff.

\section{REFERENCES}

Apuke, O. D. (2017). Quantitative Research Methods: A Synopsis Approach. Kuwait Chapter of Arabian Journal of Business and Management Review, 6(11), 40-47. https://doi.org/10.12816/0040336

Beauregard, A., Basile, K., \& Canonico, E. (2013). Home is where the work is: in ACAS and beyond. In ACAS Research Publications. https://doi.org/10.1089/ast.2006.0095

Dr. Revenio C. Jalagat, J., \& Jalagat, A. M. (2019). Rationalizing Remote Working Concept and Its Implications on Rationalizing Remote Working Concept and. Global Journal of Advanced Research, (June).

(c) 2021 International Journal of Management, Entrepreneurship, Social Science and Humanities (IJMESH) ISSN 2580-0981 (online) 
International Journal of Management, Entrepreneurship, Social Science and Humanities (IJMESH), Vol. 4 (1), 32-40 Impact of Work-From-Home Policy on Behavior and Productivity of Lecturers and Education Staff Afni Sirait; Sri Luna Murdianingrum

Erickson, R., Moulton, D., \& Cleary, B. (2018). Are you overlooking your greatest source of talent? Deloitte Review, (23), 42-51.

Frey, C. B., Ainley, J., Curmi, E., Garlick, R., Pollard, M., Chen Oxford Martin Fellow, C., ... Pritchard, W. H. (2020). Technology at Work: A New World of Remote Work. In Citi GPS: Global Perspectives \& Solutions.

Global Research Study. (2020). Technology and the Evolving World of Work.

Gordon, J., \& Gretton, P. (2015). On productivity: Concepts and measurement. Australian Government Productivity Commission, (February), 23.

Longino, H. E., \& Longino, H. E. (2015). Defining Behavior. Studying Human Behavior, 151-178. https://doi.org/10.7208/chicago/9780226921822.003.0009

MacRae, I., \& Sawatzky, R. (2020). Remote Working : Personality and Performance Research Results Prepared by Ian MacRae and Roberta Sawatzky.

Mautz, S. (2018). A New Study Reveals Why Working From Home Makes Employees More Productive | Inc.com.

Mungkasa, O. (2020). Bekerja dari Rumah (Working From Home/WFH): Menuju Tatanan Baru Era Pandemi COVID 19. Jurnal Perencanaan Pembangunan: The Indonesian Journal of Development Planning, 4(2), 126-150. https://doi.org/10.36574/jpp.v4i2.119

Navrátil, M. M., Hladká, M. M., David, M. D., \& Duspivová, I. K. P. D. (2017). Remote Work Problems and Their Solution for Employees.

Nordin, N. N., Mohd Baidzowi, F. M., \& Razak, R. A. (2016). Understanding the Work At Home Concept, Its Benefits and Challenges Towards Employees. Social Sciences Research, 2016(July), 109-118.

Rapp, A., Tirassa, M., \& Tirabeni, L. (2019). Rethinking technologies for behavior change: A view from the inside of Human change. ACM Transactions on Computer-Human Interaction, 26(4). https://doi.org/10.1145/3318142

Rupietta, K., \& Beckmann, M. (2018). Working from Home: What is the Effect on Employees' Effort? Schmalenbach Business Review, 70(1), 25-55. https://doi.org/10.1007/s41464-017-0043-x

Saludin, N. A., Karia, N., \& Hassan, H. (2020). Working from Home (WFH): Is Malaysia ready for digital society? Entrepreneurship Vision 2020: Innovation, Development Sustainability, and Economic Growth - Proceedings of the 20th International Business Information Management Association Conference, IBIMA 2013, 981-989.

Song, Y., \& Gao, J. (2018). DISCUSSION PAPER SERIES Does Telework Stress Employees Out? A Study on Working at Home and Subjective Well-Being for Wage / Salary Workers Does Telework Stress Employees Out? A Study on Working at Home and Subjective Well-Being for Wage / Salary Workers. IZA Discussion Paper, (11993), 2.

Timsal, A., \& Awais, M. (2016). Flexibility or ethical dilemma: an overview of the work from home policies in modern organizations around the world. Human Resource Management International Digest, 24(7), 12-15. https://doi.org/10.1108/HRMID-03-2016-0027

TOPCONTENT. (2019). 13 Best Countries in the World when Working from Home. Retrieved August 6, 2020, from TOPCONTENT website: https://topcontent.com/for-writers/blog/bestcountries-work-from-home/

Wong, K., \& Kwong-Kay. (2016). Mediation Analysis, Categorical Moderation Analysis, and HigherOrder Constructs Modeling in Partial Least Squares Structural Equation Modeling (PLS-SEM): A B2B Example Using SmartPLS. The Marketing Bulletin, 26(May), 1-22. https://doi.org/10.13140/RG.2.1.1643.0562

Yilma Goshu, Y., Kitaw, D., \& Matebu, A. (2017). Development of Productivity Measurement and Analysis Framework for Manufacturing Companies. Journal of Optimization in Industrial Engineering, 22(April), 1-13. https://doi.org/10.22094/joie.2017.274 